DOI https://doi.org/10.30525/978-9934-588-37-2.1.13

\title{
PERSONALITY TRAITS OF ENTREPRENEUR IN PSYCHOLOGICAL RESEARCH
}

\section{Dubravska N. M., Skovliuk D. Yu.}

\section{INTRODUCTION}

Society is becoming more and more aware that entrepreneurship is one of the important factors in the formation and development of market economy with a place for state regulation. Advanced entrepreneurship needs appropriate economic, political, social and legal conditions today more than ever. Without it a country can not overcome deep economic crisis, start the path of sustainable economic progress or enter global economy as an equal subject of international relations.

There is no doubt that in the modern market economy the personality of entrepreneur occupies one of the central places, which in turn enhances the relevance of comprehensive study of entrepreneurs, in order to identify such individual-psychological patterns in the traits of their personality, that affect the stability and efficiency of enterprise.

The today's reality indicates that there is an urgent need for skilled entrepreneurs (increasing number of business schools, business classes in educational institutions, etc.). Foreign and domestic scientists research is traditionally based on a structural approach that studies the motivation, personality traits of entrepreneurs, moral and ethical characteristics of businessmen.

For a long period of timet he world science has been engaged in the theory and practice of entrepreneurship. The factors of successful professional entrepreneural activity are studied by philosophers, economists, sociologists, and psychologists. A spectrum of individual psychological qualities that a successful enterpreneur possess has closely been studied in the writings of foreigners (K. Warnerid, P. Davidson, P. Drucker, W. Zombart, M. Cets-de-Vries, A. Marshall, A. Martinelli, M. McCoby, F. Night, M. Peters, J.-B. Sei, A. Smith, R. Hizrich, Y. Shumpeter, etc.) and Ukrainian scientists (O. Bondarenko, N. Dubravska, V. Kolot, V. Kostiuk, O. Levtsun, L. Lysenko, M. Mishchenko, Y. Pachkovsky, N. Pobirchenko, S. Pokropivny, O. Serhiyenkova, M. Sobol, Y. Shvalb, etc.).

A large number of scientific publications is devoted to the study of personal traits of success entrepreneurs. However, in the globalized world today this issue is not sufficiently explored as studies often produce 
conflicting results. The most important place among the studies of the entrepreneurial psychology is occupied by researches that contain certain list of psychological characteristics as a part of the "entrepreneurial personal profile". Obviously, each of these characteristics does not exhaust all the qualities necessary to ensure the efficiency of business activity.

The analysis and integration of numerous research works aimed at distinguishing personal determinants of successful business activity made it possible to include such traits as motivation of achievement, willingness to risk, internal locus of control and innovation to the list of the most typical traits.

Herewith, there is little attention paid to the study of temperament, which is forms a basis for the formation of human personality. This is what does not allow to create a comprehensive multifaceted characteristic of the entrepreneur's personality. This also gives rise to difficulties in providing real advisory assistance to start-up businesses as well as in the formation of retraining groups in employment services. In this regard, it is important to comprehensively study the identity of successful entrepreneurs by temperamental characteristics.

\section{Motivational orientation of entrepreneurs}

The first psychological study of an entrepreneur's personality is a study of the motivation of achievement in business, conducted by D.Mak-Clelland in the early 60 's ${ }^{1}$. The study, the theoretical basis of which was the theory of achievement motivation, was the first attempt to find out whether entrepreneurs tend to create a specific "psychological class" that is significantly different from the rest of the non-entrepreneurial population.

D. McClelland advocated the indisputable motive of achievement as a significant incentive for business and saw entrepreneurs as people who can take high responsibility. The entrepreneur is characterized by the highest level of motive for achievement, which is related to his desire to achieve the goals, either determined by social norms or set independently. Analyzing the formation conditions of achievement motivation, D. McClelland identifies 4 main groups of contributing factors: introspection, development of optimal goal-setting tactics, interpersonal support, formation of achievement syndrome, which envisages in its perspective a number of actions, among which is giving advantages to medium-sized goals, achievement which depends on the skills and abilities of the actor himself; avoiding both too

\footnotetext{
${ }^{1}$ McClelland D.C. Achivement and entrepreneurship: A longitudinal study. Journal of Personality and social Psychology. 1965. Vol. 1. P. 389-392. McClelland D.C., Boyatzic R.E. Leadership motive pattern and long-term success in management. Journal of Applied Psychology. 1982. Vol. 67. P. 737-743.
} 
easy and too difficult goals; taking personal responsibility for the outcome of the case; avoiding situations where the goal is set by other people.

According to the necessary empirical data, D. McClelland argues that entrepreneurs should have a highly developed need for achievement, which, in turn, determines a certain set of behavioral characteristics and personal traits. According to McClelland, persons with motivation to achieve are characterized by the following characteristics: confidence in the success of the case, active search for information to evaluate their own success, willingness to take responsibility and determination in situations of uncertainty, high perseverance in achieving the goal, pursuit of reasonable risk, a realistic level of harassment, an increase in the level of harassment after success and a decrease after failure.

Empirical studies of future specialists on the manifestation of their motivation for achievement included three stages. During the first phase of the longitudinal study, D. McClelland found that students with high levels of achievement motivation demonstrated the superiority of a businessman's professional status over that of a professional. The second phase of the study found that $83 \%$ of the students who eventually became entrepreneurs had high levels of motivation to achieve in the first phase of the study, and only $21 \%$ of students who chose non-business related professions showed similar rates 17 years ago. Testing former college students seven years after graduation showed similar results: $60 \%$ of entrepreneurs, compared with $41 \%$ of non-entrepreneurs, had a high level of motivation to achieve when they were freshmen.

Based on a number of similar data, D. McClelland concludes that the high level of motivation to achieve influences the formation of the decision to engage in business.

The third stage of the research, conducted within the framework of training programs for the development of achievement motivation in businessmen, showed that in $48 \%$ of cases, increasing the motivation to achieve as a result of training leads to a sharp increase in business activity, and as a result, to increase the success of entrepreneurial activity. The data obtained led the author of the concept to conclude that a high level of motivation to achieve not only predicts professional choice, but also ensures the success of entrepreneurial activity.

The concept of D. McLelland's entrepreneurial personality studies entrepreneur's behavior as directed toward the achievement of a specific goal - success. This trend of personality research characterizes domestic psychology as adaptive ${ }^{2}$. This model identifies only a motivational level of

2 Асмолов А.Г. Психология личности: принципы общепсихологического анализа. Москва : МГУ, 1990. 367 с. 
motivation when, as "for a person more specific and hierarchically higher, there is a substantive and semantic level of motivation. At this level, motivational regulation of the most complex forms of human activity is carried out, which is characterized by an active, "initiative" attitude to reality, not just an adaptive one" 3 .

The concept of D. McLelland has attracted considerable interest among scientists, and almost all practical studies of the present on personal psychology contain the results of measuring the index of achievement motivation in entrepreneurs ${ }^{4}$.

The study of the influence of the dominance of one or another motive the motive of achievement, affiliation, power - on the success of entrepreneurial activity was engaged in by foreign psychologists B. Weiner, I. Rubin ${ }^{5}$. They found that the economic success of the company is facilitated by a high motive for achievement (among executives) and a low motive for affiliation, the magnitude of the motive of the authorities is insignificant. However, according to other studies, the role of the power motive is considered differently, either the average one is considered optimal or its high level. However, all researchers emphasize the importance of expressing the motive of achievement in entrepreneurs for successful completion of the case and the negative correlation of the latter with the motive of affiliation.

We are led to such conclusions by the results of a study by a national scientist M. Mischenko ${ }^{6}$, who found that psychologically competitive entrepreneurs have more than "weak" orientation towards an active life, which, in our opinion, is one of the components motivation to achieve, and in the "weak" - the presence of good and loyal friends, which is a factor in the motivation of affiliation.

Summarizing the experimental data in the field of success motivation, we can agree with $\mathrm{B}$. Weiner ${ }^{7}$ that among individuals with a pronounced desire for achievement in the case of failure, motivation only increases, and in the

\footnotetext{
${ }^{3}$ Васильев И.А., Магомед-Эминов М.Ш. Мотивация и контроль за действием. Москва : МГУ, 1991. 144 с.

${ }^{4}$ Davidson P. Need for Achievement and Entrepreneural Activity in Small Firms. Understanding Economic Behavior / ed. by K.G. Grunert, F. Olander. Kluwer Academic Publishers. 1989. P. 47-64.

${ }^{5}$ Wainer H.A., Rubin I.A. Motivation of research and development entrepreneurs Determinants of company success. Journal of Applied Psychology. 1969. Vol. 53. P. 178-184.

6 Міщенко М. Підприємець сьогодні: штрихи до соціально-психологічного портрета. Філософська і соиіологічна думка. 1993. № 6. С. 61-69.

Wainer H.A., Rubin I.A. Motivation of research and development entrepreneurs Determinants of company success. Journal of Applied Psychology. 1969. Vol. 53. P. 178-184.
} 
case of success, it decreases. Conversely, with a low level of need for success, success increases motivation, and failure weakens it.

Thus, an analysis of meaningful theories of motivation can explain some aspects of an individual's motivational attitudes toward entrepreneurship. These theories are aimed at analyzing the factors that influence a person's behavior, his or her labor activity through achieving his/her own needs. What is common to them is that they determine the basis of motivation for the needs of specific people. These needs in the human mind are transformed into interests, motives, which actually stimulate it to certain purposeful actions. Since the key element of all meaningful theories is the identification of the influence of different needs on human behavior in work, on the basis of analysis of the results of modern experimental research, we will try to identify those primary motives, the driving forces that are important for attracting an individual to a new sphere of social activity for him.

Using the terminology of the German psychologists B. Schwalbe and H. Schwalbe ${ }^{8}$, J. Pachkovsky ${ }^{9}$ in this case speaks of the so-called introverted motivation, which, in his opinion, reflects actions that are conscious and carried out by one's choice. In contrast to introverted, extraverted motivation is conditioned by material rewards, social status, prestige and regulating influence on the activity of the individual.

The analysis of the motivational sphere of entrepreneurs of economically developed countries shows that money, material well-being - is not an end in itself for entrepreneurs. Important for them is the desire to become wealthy quickly in order to gain more freedom in their future endeavors ${ }^{10}$. According to American researchers, in the structure of the motivational sphere, the motive for acquiring through entrepreneurship of one's own independence is crucial, and the rest of the motives play only ancillary role $^{11}$. Close to this view are the views of British scientists, who say that the main motivation for entrepreneurship is the motive of "independence" - the desire to be the master of their own destiny, the opportunity to choose their own occupation and place of work. The "financial advantage" motif took second place ${ }^{12}$.

${ }^{8}$ Швальбе Б., Швальбе Х. Личность, карьера, успех / пер. с англ. Москва : Прогресс, 1993. 240 с.

9 Пачковський Ю.Ф. Соціопсихологія підприємницької діяльності і поведінки. Львів : Світ, 2000. 272 с.

10 Хруцкий В.Е. Как стать предпринимателем. США: экономика, политика, идеология. 1992. № 9. С. 96-99.

11 Хизрич Р., Питерс М. Предпринимательство, или как завести собственное дело и добиться успеха. Москва : Прогресс. 1991. Вып. 1. 160 с.

12 Данишевская Г.А. «Самостоятельные работники» в Великобритании. СОЦИС. 1992. № 9. C. 124-133. 
Studies by N. Dubravska ${ }^{13}$ show that in assessing the personal value of entrepreneurial values, such a motive for the pursuit of pragmatic success money and material gain as the ultimate goal - rank below the fifth. Entrepreneurs most appreciate the opportunity to exchange views with colleagues and jointly develop decision-making procedures. They associate the level of professionalism with the possibilities of self-actualization and enjoyment of their work.

Such a distribution of motives is somewhat characteristic of representatives of our business. The hierarchy of entrepreneurial motives highlighted by A.Chirikova ${ }^{14}$ indicates a marked dominance in the structure of motivation of the business elite proper professional characteristics and components of self-affirmation with significant, but not leading motive for material security.

According to A. Zhuravlev and V. Poznyakova ${ }^{15}$, for the subjects of entrepreneurial activity the greatest motivating force of motives connected with the desire for personal independence and the desire to realize their professional abilities was stated. This conclusion is reached and studies conducted among domestic entrepreneurs, led in our research ${ }^{16}$. The results of the poll indicate that people in business are mostly attracted by the "opportunity to act on their own", "the opportunity to show their skills while doing interesting work" and only then "high income".

Thus, at the heart of the motivational and dynamic strategy of researching the personality of entrepreneurs is the theoretical proposition that motivation to achieve is the main personal determinant that determines the success of professional activity of entrepreneurs. The complexity of the problem of creating a systematic psychological representation of the motivational tendencies that underlie entrepreneurial activity, allows us to make the assumption that entrepreneurship is inherently connected with the

13 Дубравська Н.М., Сидоренко Н.І..Актуалізація особистісних детермінант успішної професійної підготовки майбутніх підприємців. Наука і освіта. 2016. № 5. C. $172-177$.

Дубравська Н.М. «Успіх» і «невдача» як індивідуально-особистісні кореляти підприємницької поведінки. Вісник Київського інституту бізнесу та технологій. 2018. № 3 (37). С. 82-85.

Дубравська Н.М. Індивідуально-психологічний вимір особистості підприємця. Вісник Київського інституту бізнесу та технологій. 2019. № 1 (39). С. 102-106.

14 Чирикова А.Е. Лидеры российского предпринимательства: менталитет, смыслы, ценности. Москва : Институт социологии, 1997. 203 с.

15 Журавлёв А.Л., Позняков В.П. Социально-психологические трудности становления малого бизнеса в России (анализ группового мнения предпринимателей. Психологический журнал. 1993. № 6. С. 18-26.

16 Дубравська Н.М. Професійна підготовка майбутніх підприємців: теоретичний аспект. Вісник Київського інституту бізнесу та технологій. 2017. № 3 (34). C. $29-35$. 
awareness of self-realization, personal growth, self-independence and autonomy in actions precisely through the activities of this direction, which is exactly the source of activity that determines the activity and behavior of a business person, forms the basis of his motivation, in particular the motivation to achieve.

\section{Locus of control and risk appetite as a prerequisite for successful business activity}

The moment of assuming responsibility and control over circumstances was developed in many studies of entrepreneurship that were in line with the theory of locus of control of J. Rotter, according to which the high motivation to achieve is connected primarily with the internal locus of control. Based on the research of D. McClelland, J. Rotter argued that, on the one hand, people with high motivation to achieve tend to be confident in their ability to control the results of their own efforts, and on the other hand, people with an internal locus of control are more likely to fight for achievement than people with an external locus of control ${ }^{17}$.

A number of studies have confirmed the hypothesis of an internal type of locus of control in entrepreneurs. At the same time, it has been proved that the internally controlled entrepreneur is more active and proactive than the external one ${ }^{18}$. R. Borland noted that confidence in one's own ability to control events is even a better harbinger of entrepreneurial intentions than high motivation to achieve ${ }^{19}$. R. Brockhaus found that potential entrepreneurs have higher internality rates than students who plan to become managers ${ }^{20}$. The same author found that successful entrepreneurs are much more interned than unsuccessful ones.

In addition to the ones mentioned above, there is a whole body of research into the locus of control in entrepreneurs, the results of which are quite ambiguous. Some researchers have therefore suggested that the high motivation to reach and the internal type of locus of control do not distinguish entrepreneurs from other professional groups, but separate them into successful and unsuccessful ${ }^{21}$.

The inconsistency of the results of the study of the locus of control, same as the motivation to achieve, as well as other traits and characteristics of the

17 Warneryd K.-E. The psychology of innovative enterpreneurship. Handbook of economic psychology. Dorderecht, Boston, London. 1988. P. 404-447.

${ }^{18}$ Ibid.

${ }^{19}$ Brockhaus R.H. Risk taking propensity of entrepreneurs. Academy of Managment Journal. 1980. Vol. 23. № 3. P. 509-520.

${ }^{20}$ Ibid.

${ }^{21}$ Hisrich R.D. Enterpreneurship / Intrepreneurship. American Psychologist. 1990. Vol. 45. № 2. P. 209-222. 
entrepreneur's personality, once again testifies to the futility of efforts to identify a universal entrepreneurial profile outside the cultural and personalsemantic aspect. In this regard, it is not accidental that many psychologists are interested in the cross-cultural aspects of the problem. For example, it has been found that in some countries there are internally or externally installed cultural facilities. Yes, in some cultures, fatalistic preferences are opposed to South American optimism. The external type of attribution, and hence "uncertainty about the future and a pessimistic economic outlook can hinder investment and lead to loss of entrepreneurial opportunities" 22 , which occurs in Latin American and African cultures, where there is no need for value and investment. in material accumulation.

The risk parameter as an integral characteristic of a successful entrepreneur's personality is subject to analysis in many studies and publications, however, the results of studies of this aspect of business activity are quite controversial. Analysis of scientific sources has shown that in psychology, risk is mainly studied within the framework of the theory of motivation, decision theory and the concept of supersituative activity. Different approaches also imply a different understanding of the risk phenomenon. Let us distinguish some of them.

Risk can mean "appeal to the activity in the absence of confidence in achieving its goals" ${ }^{, 23}$. At risk is an action aimed at an attractive goal, the achievement of which is combined for the individual with the elements of the threat of danger, loss, failure, $\operatorname{etc}^{24}$.. The combination of the two approaches creates the preconditions for considering risk as a situational characteristic of an activity that involves uncertainty about the outcome and possible adverse effects in the event of failure.

Sometimes the risk can be seen as a measure of the expected failure, the failure of a failure in the activity. This measure is determined by the ratio of the probability of failure and the degree of adverse effects that may occur in this case.

In some studies, risk is understood as a situation of no choice between some options: less attractive, but more reliable, and more attractive, less reliable. The second option is always problematic and has the potential for adverse effects. This approach to understanding the essence of the concept of "risk" allows, within the concept of achievement motivation to explain

${ }^{22}$ Gasse Y. Elaborations on the psychology of the entrepreneur. Encyclopedia of enterpreneurship. New Jersey, 1982. P. 57-66. Академвидав. 2006. 424 с.

24 Дубравська Н.М. «Успіх» і «невдача» як індивідуально-особистісні кореляти підприємницької поведінки. Вісник Київського інституту бізнесу та технологій. 2018. № 3 (37). С. 82-85. 
manifestations in the personality tendency to risk in terms of free choice of tasks of different levels of complexity, to explain the relationship between traits and qualities of a person, his temperament, motives of behavior, on the one hand, and an exaggerated or low risk appetite from another.

The empirical level is justified by the position of D. McClelland, who notes that the key to the success of entrepreneurial activity is mainly the average level of risk characteristics of entrepreneurs ${ }^{25}$. R. Brockhaus did not find any difference in this parameter between entrepreneurs and managers ${ }^{26}$. The reason should be sought in the complexity of the phenomenon of risk, in existence in addition to the level of risk of its various types, components and aspects. This researcher identifies three components of risk - the general propensity to risk, the perception of the likelihood of failure and the perception of the consequences of failure. K. Wernerid proposes to combine the theory of attribution with the theory of risk perception ${ }^{27}$, and therefore emphasizes that it is more appropriate to talk about the perception of risk by the entrepreneur, rather than the risk, the degree of which is assessed by an "objective" external observer. According to K. Wernerid, entrepreneurs are only active in situations of subjectively low risk, when they perceive themselves to be the masters of the situation, being confident that they have sufficient ability to master the situation. The validity of such an "illusion of control" is determined by the nature of the subjective perception of the surrounding conditions and personal abilities of the entrepreneur.

R. Radlic proposed a theory of risk that distinguishes between those who introduce a specific risk into an existing one and those who assume that risk $^{28}$. He views the entrepreneur as a person who takes the risk associated with management and decision-making and therefore confronts the entrepreneur with the manager. A. Doctors and K. Juris argue that an entrepreneurial person takes a high risk to achieve certain goals, while a manager prefers stability, security, and predictability of situations in the organization $^{29}$. Often, entrepreneurs are also credited with the sociopsychological function of risk absorption, which is to create for others the "illusion» of an absolute guarantee of success ${ }^{30}$.

${ }^{25}$ McClelland D.C. Achivement and entrepreneurship: A longitudinal study. Journal of Personality and social Psychology. 1965. Vol. 1. P. 389-392.

${ }^{26}$ Brockhaus R.H. Risk taking propensity of entrepreneurs. Academy of Managment Journal. 1980. Vol. 23. № 3. P. 509-520.

${ }^{27}$ Warneryd K.-E. The psychology of innovative enterpreneurship. Handbook of economic psychology. Dorderecht, Boston, London. 1988. P. 404-447.

${ }^{28}$ Gasse Y. Elaborations on the psychology of the entrepreneur. Encyclopedia of enterpreneurship. New Jersey. 1982. P. 57-66.

${ }^{29}$ ibid

30 Schein E.N. The role of the founder in creating organizational culture. Organizational Dinamics. 1983. Vol. 12. P. 13-28. 
Thus, the analysis of studies of entrepreneurs' personality in the context of risk aversion does not give an unambiguous view, which would indicate the benefit of highlighting this characteristic as a universal determinant of successful professional activity of entrepreneurs.

\section{Cognitive and temperamental personality structures of entrepreneurs}

A review of the literature showed that the scientists often attribute the presence of specific features of cognitive stylet to the personality of the entrepreneur. In particular, the predominance of intuitive thinking over rationa $^{31}$, innovative thinking as opposed to adaptive ${ }^{32}$, functioning of a special kind of "heuristic", which determines the creativity of his thinking ${ }^{33}$.

In general, the innovative type of entrepreneurial behavior is determined by a high willingness to overcome various obstacles in the implementation of innovations, a stable ability to work in extreme situations of high risk and uncertainty, personal ability to neutralize conservative stereotypes, opposition sentiment. Significant personality traits of the subject of innovative behavior include managerial skill in mobilizing all factors of production, including the involvement of all like-minded people in his team, and the constant search for opportunities ${ }^{34}$.

Innovative behavior is also characterized by the following components:

- purposefulness as a desire to achieve a certain goal;

- motivation as the desire of the individual to actively search for the new, improve the existing;

- integrity, by which is understood the completeness of personal properties and traits that ensure the ability of the individual to act as a subject of transformative activity;

- organization of the person - orderliness, collection, subordination to a certain order of performance of actions, ability to act according to the developed and established plan;

- efficiency (productivity, efficiency) of innovative behavior ${ }^{35}$.

31 Предприниматель: экономико-психологический профіль. Психологический журнал. 1992. Т. 13. № 3. С. 42-53.

Kets de Vries M.F.R. The entreprenurial personality: A person at the crossroads. Journal of Management Studies. 1977. Vol. 14. № 1. P. 34-57.

32 Kirton M.J. Adaptors and innovators in organization. Human Relations. 1980. Vol. 33. P. 213-224.

Kirton M.J. Adaptors and innovators: Why new initiativs get blocked. Long Range Planning. 1984. Vol. 17. P. 137-143.

33 Warneryd K.-E. The psychology of innovative enterpreneurship. Handbook of economic psychology. Dorderecht, Boston, London. 1988. P. 404-447.

${ }^{34}$ Петренко В.Ф. Психосемантика сознания. Моск ва : МГУ. 1988. 208 с.

35 Поляков В.А., Сасова И.А. Непрерывное экономическое образование молодёжи. Педагогика. 1994. № 4. С. 19-26. 
M. Kirton ${ }^{36}$ proposed the concept of innovation-adaptability as the main characteristics of the cognitive style of entrepreneurs and managers. The concept author views the entrepreneur's innovativeness as a specific cognitive style, characterized by "producing" gaps "in habitual patterns of thought and behavior, changing things, making them different, and not improving the old to infinity" ${ }^{37}$. The innovativeness of the entrepreneur M. Kirton contrasts with the adaptability of the cognitive style of the manager, who is inclined to solve problems in the usual way, to make any changes only within the established organizational norms.

According my opinion, entrepreneurs, in comparison with other people, function differently, because they possess special heuristics and a special character of functioning of these heuristics in a situation of risk. The presence of cognitive heuristics helps the entrepreneur to make extraordinary, creative decisions in the economic sphere of activity. Thus, applying to the context of entrepreneurship the heuristic of "representativeness" proposed by cognitive theory, K. Wernerid argues that entrepreneurs "resist the representativeness", which provokes decisions based on the similarity of a situation and an object with a certain class of situations or objects. not based on statistical estimates of the frequency of their occurrence. Entrepreneurs create their own niches or classes of situations or objects that are significantly different from conventional ones.

Cognitive theory also offers a heuristic of "concreteness", which is that people tend to remember information in exactly the same way it was received. $\mathrm{K}$. Warnerid ${ }^{38}$ considers that on the basis of real cases of success in business, known from their own or others' practice, entrepreneurs are able to transform new information so that they can immediately correct or change the standard course of action in accordance with their ideas, beliefs and own style of ethical and economic behavior.

Despite the sufficient theoretical and methodological development of the cognitive approach to the personality of the entrepreneur, the results of studies of the cognitive structures of personal determinants of successful professional activity of entrepreneurs are quite controversial. If the cognitive and motivational-cognitive approaches view the entrepreneur as rational, endowed with analytical thinking and unique information characteristics of the person, then the psychoanalytic approach characterizes the cognitive processes of the entrepreneur as "damaged". U. Hess, for example, comparing the cognitive characteristics of entrepreneurs and managers,

\footnotetext{
${ }^{36}$ Kirton M.J. Adaptors and innovators: A discription and measure. Journal of Applied Psychology. 1976. Vol. 61. P. 622-629.

${ }^{37}$ Ibid. P. 622.

38 Warneryd K.-E. The psychology of innovative entrepreneurship. Handbook of economic psychology. Dorderecht, Boston, London. 1988. P. 404-447.
} 
attributes to the entrepreneur "limited time perspective", the specificity of thinking and interest in detail, notes that "rational managerial business ideology tends to more complex, integrated ways of thinking, compared with intuition - an entrepreneurial ideology dominated by simple cognitive structures" ${ }^{\prime 39}$.

The type of temperament is the most stable characteristic of a person, which is manifested in all spheres of his life, we can assume that he is universal and is the starting point in the formation of a person's personality. Therefore, for the empirical study of professionally important individuallypsychological characteristics of the entrepreneur's personality, we conducted a study using the method "Questionnaire of Formal-Dynamic Traits of Individuality" V.M. Rusalov ${ }^{40}$.

Analyzing the results, N. Dubravska ${ }^{41}$ founds that the studied group of entrepreneurs have the maximum values such parameters as: "ergic intellectual", "speed intellectual" and "speed communicative". The indicators below the average include the values of the parameters: "emotional motor", "emotional intelligence", "emotional communicative". All other options are in the average corridor.

Analyzing the obtained values, it should be noted that the surveyed group of entrepreneurs has a high level of intellectual ability: a propensity for learning, a constant desire for activities related to mental activity. However, they have a high speed of thought processes in the implementation of intellectual activities, rapid verbalization, high speed of speech activity. This is combined with a rather low sensitivity to the differences between the planned action and the actual result; they are also characterized by a sense of calm and confidence when solving their tasks. As we can see, intellectual and communicative spheres play an important role in successful entrepreneurial activity: the ability to think rationally, make decisions, and be able to build relationships with people.

Comparing the group of entrepreneurs with the group of managers of industrial enterprises, we find that the former have significantly higher parameters in terms of "ergic intellectual", "plasticity intelligent", "plasticity communicative", "speed intellectual", "speed communicative", "emotional communicative". But at the same time, entrepreneurs have much lower scores on the scale "motor power", "communicative ergonomics", "motor

39 Gasse Y. Elaborations on the psychology of the entrepreneur. Encyclopedia of entrepreneurship. New Jersey. 1982. P. 57-66.

40 Абалкин Л.И. Заметки о российском предпринимательстве. Москва : Прогресс-Академия. 1994. 160 с.

41 Дубравська Н.М. «Успіх» і «невдача» як індивідуально-особистісні кореляти підприємницької поведінки. Вісник Київського інституту бізнесу та технологій. 2018. № 3 (37). С. 82-85. 
plasticity". Such a difference in indicators can be explained by the specific activity of both study groups. For example, managers have a more explicit desire for leadership in certain social groups and a limited set of communication programs. They are more rigid when solving abstract tasks and therefore have less tendency to learn, develop, and refresh their intellectual experience.

According to the analysis of the results of the study conducted in the group of entrepreneurs and managers by t-criterion, we have quite significant differences in the indicators in the following parameters: entrepreneurs are more expressed "plasticity intelligent", "plasticity communicative" and "speed communicative". This means that they are more flexible in processing information, appropriately verbalizing thoughts, able to quickly switch from one interlocutor to another. Managers are more expressed in motor ergonomics and motor plasticity, that is, they need activities that require ease of switching, which is a temperamental reflection of those requirements that are imposed on the personality of the head of the enterprise.

It is important to note that despite the differences in the temperamental profile of students and managers, analysis of these data by the t-test did not reveal the stability of these properties. Probably, this fact can be explained by the fact that many graduate students aspire to make a career in the enterprises of the city, and therefore when selecting students in the universities there is a natural selection of persons capable of such activity, that is, they must necessarily have the prerequisites for it. This is exactly what was discovered.

\section{CONCLUSIONS}

The professional activity of entrepreneurs, caused by radical socioeconomic transformations in the countries, is gradually becoming an integral sign of successful functioning of entrepreneurs in the field of business, and the entrepreneur's personality acquires a comprehensive study in many social sciences. Generalization of the results of theoretical analysis of the scientific literature on the problem of personal determinants of successful professional activity of entrepreneurs showed that there are many approaches to solving it. However, most of the conceptual models of entrepreneur personality considered above are based on separate explanatory principles, rarely describing the personal determinants of his professional activity as a whole, taking into account ethical aspects. They are distinguished by the lack of a unified methodological approach to the problem, the focus on individual personality traits and characteristics that determine the success of professional activity.

A review of the scientific literature has shown that an objective or functional approach to determining the personal determinants of successful 
professional activity of entrepreneurs leaves out of consideration the "internal moment" of entrepreneurial activity, namely, that allows the specialist to carry out effectively the entrepreneurial functions. The identity of the entrepreneur should be considered as a carrier of a certain way of life with characteristic of the entrepreneurial professional ethnos worldview, values and ideals, stereotypes and symbols.

Paying due logic to the selection of a number of scientists of the most typical personal determinants of successful entrepreneurial activity (high level of achievement motivation, willingness to risk, internal type of locus of control, innovativeness in behavior), we note that their analysis did not give unambiguous conclusions, distinguishing them as universal entrepreneurial psychological characteristics, or as those that could act as personal determinants of successful professional training for future entrepreneurs.

According to the results of the study, entrepreneurs, to a lesser extent than managers, seek leadership and strenuous physical labor, but are more prone to personal self-development and intellectual improvement. They are more flexible in their decision making and communication with people. These individual-psychological characteristics, in our opinion, and ensure the success and stability of functioning in business.

That is why the systematic approach in determining the personal determinants of successful professional activity of entrepreneurs, which we tried to implement in this study from the standpoint of a subjective approach, forecasts for the further study not individual psychological characteristics, but holistic systems of individual functioning of specialists in the field of entrepreneurship. Personal and professional personality is offered as such a system that determines the success of the entrepreneurs.

\section{SUMMARY}

This scientific study presents the generalized results of theoretical analysis of the scientific literature on the problem of individualpsychological characteristics of successful entrepreneurial behavior. It is shown that the most typical personal determinants of successful business, according to many scientists, are the motivation to achieve, willingness to take risks, the internal type of locus of control and innovation. It is specified that the motivation to achieve is the main personal quality that determines the success of entrepreneurs' professional behavior. It is observed that scientists often attribute to the personality of the entrepreneur the presence of specific features of cognitive style, in particular, the predominance of intuitive thinking over rational, innovative thinking as opposed to adaptability and functioning of a special kind of "heuristics" that determine the creativity of his / her thinking. It is proved that the innovative type of entrepreneurial behavior is determined by high readiness to overcome 
various obstacles in the implementation of innovations, stable ability to work in extreme situations of high risk and uncertainty, personal ability to neutralize conservative stereotypes and opposition. At the same time, the research analysis of the entrepreneurs' personality in the context of risk appetite does not give an unambiguous view, which would indicate in favor of the allocation of this characteristic as a universal determinant of successful professional activity of entrepreneurs.

\section{REFERENCES}

1. Абалкин Л.И. Заметки о российском предпринимательстве. Москва : Прогресс-Академия, 1994. 160 с.

2. Асмолов А.Г. Психология личности: принципы общепсихологического анализа. Москва : МГУ, 1990. 367 с.

3. Васильев И.А., Магомед-Эминов М.Ш. Мотивация и контроль за действием. Москва : МГУ, 1991. 144 с.

4. Данишевская Г.А. «Самостоятельные работники» в Великобритании. СОЦИС. 1992. № 9. С. 124-133.

5. Дубравська Н.М., Сидоренко Н.I. Актуалізація особистісних детермінант успішної професійної підготовки майбутніх підприємців. Наука і освіта. 2016. № 5. С. 172-177.

6. Дубравська Н.М. «Успіх» і «невдача» як індивідуальноособистісні кореляти підприємницької поведінки. Вісник Київського інституту бізнесу та технологій. 2018. № 3 (37). С. 82-85.

7. Дубравська Н.М. Індивідуально-психологічний вимір особистості підприємця. Вісник Київського інституту бізнесу та технологій. 2019. № 1 (39). С. 102-106.

8. Дубравська Н.М. Професійна підготовка майбутніх підприємців: теоретичний аспект. Вісник Київського інституту бізнесу та технологій. 2017. № 3 (34). С. 29-35.

9. Журавлёв А.Л., Позняков В.П. Социально-психологические трудности становления малого бизнеса в России (анализ группового мнения предпринимателей. Психологический журнал. 1993. № 6. C. $18-26$.

10. Міщенко М. Підприємець сьогодні: штрихи до соціальнопсихологічного портрета. Філософська і соиіологічна думка. 1993. № 6. C. 61-69.

11. Пачковський Ю.Ф. Соціопсихологія підприємницької діяльності і поведінки. Львів : Світ, 2000. 272 с.

12. Петренко В.Ф. Психосемантика сознания. Москва : МГУ, 1988. $208 \mathrm{c}$.

13. Психологічна енциклопедія / автор-упоряд. Степанов О.М. Київ : Академвидав, 2006. 424 с. 
14. Поляков В.А., Сасова И.А. Непрерывное экономическое образование молодёжи. Педагогика. 1994. № 4. С. 19-26.

15. Предприниматель: экономико-психологический профиль. Психологический журнал. 1992. Т. 13. № 3. С. 42-53.

16. Хизрич Р., Питерс М. Предпринимательство, или как завести собственное дело и добиться успеха. Москва : Прогресс. 1991. Вып. 1. $160 \mathrm{c}$.

17. Хруцкий В.Е. Как стать предпринимателем. США: экономика, политика, идеология. 1992. № 9. С. 96-99.

18. Чирикова А.Е. Лидеры российского предпринимательства: менталитет, смыслы, ценности. Москва : Институт социологии. 1997. $203 \mathrm{c}$.

19. Швальбе Б., Швальбе Х. Личность, карьера, успех / пер. с англ. Москва : Прогресс, 1993. 240 с.

20. Brockhaus R.H. Risk taking propensity of entrepreneurs. Academy of Managment Journal. 1980. Vol. 23. № 3. P. 509-520.

21. Davidson P. Need for Achievement and Entrepreneural Activity in Small Firms. Understanding Economic Behavior / ed. by K.G. Grunert, F. Olander. Kluwer Academic Publishers. 1989. P. 47-64.

22. Gasse Y. Elaborations on the psychology of the entrepreneur. Encyclopedia of enterpreneurship. New Jersey, 1982. P. 57-66.

23. Hisrich R.D. Enterpreneurship / Intrepreneurship. American Psychologist. 1990. Vol. 45. № 2. P. 209-222.

24. Kets de Vries M.F.R. The entreprenurial personality: A person at the crossroads. Journal of Management Studies. 1977. Vol. 14. № 1. P. 34-57.

25. Kirton M.J. Adaptors and innovators in organization. Human Relations. 1980. Vol. 33. P. 213-224.

26. Kirton M.J. Adaptors and innovators: Why new initiativs get blocked. Long Range Planning. 1984. Vol. 17. P. 137-143.

27. Kirton M.J. Adaptors and innovators: A discription and measure. Journal of Applied Psychology. 1976. Vol. 61. P. 622-629.

28. McClelland D.C. Achivement and entrepreneurship: A longitudinal study. Journal of Personality and social Psychology. 1965. Vol. 1. P. 389-392.

29. McClelland D.C., Boyatzic R.E. Leadership motive pattern and long-term success in management. Journal of Applied Psychology. 1982. Vol. 67. P. 737-743.

30. Schein E.N. The role of the founder in creating organizational culture. Organizational Dinamics. 1983. Vol. 12. P. 13-28. 
31. Wainer H.A., Rubin I.A. Motivation of research and development entrepreneurs - Determinants of company success. Journal of Applied Psychology. 1969. Vol. 53. P. 178-184.

32. Warneryd K.-E. The psychology of innovative enterpreneurship. Handbook of economic psychology. Dorderecht, Boston, London. 1988. P. 404-447.

\section{Information about the authors:} Dubravska N. M.,

$\mathrm{Ph} . \mathrm{D}$ in Psychological Sciences, Zhytomyr Ivan Franko State University 40, Velyka Berdychivska str., Zhytomyr, Ukraine

Skovliuk D. Yu., M.A. Master in International Economic Relations

(World Economic Conjecture) Taras Shevchenko National University of Kyiv, M.A. Master of Advanced International Studies,

Diplomatic Academy of Vienna, Specialist in international economic relations with focus on world business climate,

Team assistant at the Embassy \& Permanent Mission of the Hashemite Kingdom of Jordan to the UN in Austria, Slovenia, Slovakia, Hungary and Czech Republic Beethovengasse 3/15, Vienna, 1090, Austria 